\title{
Lexis
}

Journal in English Lexicology

$6 \mid 2011$

Diminutives and Augmentatives in the Languages of the World

\section{A Cross-Linguistic Research into Phonetic Iconicity}

Lívia Körtvélyessy

\section{(2) OpenEdition \\ Journals}

Electronic version

URL: http://journals.openedition.org/lexis/409

DOI: $10.4000 /$ lexis.409

ISSN: 1951-6215

\section{Publisher}

Université Jean Moulin - Lyon 3

Electronic reference

Lívia Körtvélyessy, «A Cross-Linguistic Research into Phonetic Iconicity », Lexis [Online], 6 | 2011, Online since 27 March 2011, connection on 02 May 2019. URL : http://journals.openedition.org/ lexis/409 ; DOl : 10.4000/lexis.409

\section{(c) $(1)$}

Lexis is licensed under a Creative Commons Attribution-NonCommercial-NoDerivatives 4.0 International License. 


\title{
A Cross-Linguistic Research into Phonetic Iconicity
}

Lívia Körtvélyessy ${ }^{1}$

\begin{abstract}
Phonetic iconicity in evaluative morphology is an integral part of sound symbolism in natural languages. Former research in this field has brought contradictory results. On the one hand, there is Universal \#1926 (Plank and Filimonova's Universals Archive, Konstanz) claiming universal marking of diminutives by front high vowels, and of augmentatives by high back vowels. Furthermore, there are papers extending the idea of phonetic iconicity to the frontback opposition of consonants. On the other hand, there are studies (Ultan [1978], Nieuwenhuis [1985], Gregová, Körtvélyesssy and Zimmermann [2009]) indicating that (a) this phenomenon is of areal rather than universal nature; (b) there are substantial differences between languages within individual genetic families, (c) front high vowels are typical of augmentatives rather than diminutives; diminutive affixes are acoustically realized by central vowels

The paper presents the results of cross-linguistic research into a balanced sample of 60 languages of the world. The focus is this time on the verification of the hypothesis in question by comparing languages of various genetic, geographical and morphological types. Special attention is paid to (a) checking the postulated front-back opposition in languages with both morphological diminutives and augmentatives, (b) the relevance of phonetic iconicity in terms of geographical, genetic, and morphological classifications of the sample languages; comparison of the data obtained with the results arrived at in the previous stages of our research which dealt with 35 European languages. The discussion is supported by numerous examples.
\end{abstract}

Keywords: diminutives - augmentatives - phonetic iconicity - cross-linguistic research

\footnotetext{
${ }^{1}$ P.J. Šafárik University, Košice, Slovakia: livia.kortvelyessy@upjs.sk
} 


\title{
1. Introduction
}

This paper was motivated by the Universals and Typology in Word-Formation conference (Košice, August 2009). Encouraged by a positive response to our presentation ${ }^{2}$ on phonetic iconicity I decided to take up a follow-up research, and to compare languages of Europe and Africa in terms of phonetic iconicity in evaluative morphology. I could rely on a comprehensive database characterizing languages of the world according to various evaluative morphology parameters. A general background for my research and the state-ofthe-art in the field are outlined in Section 2, followed by the specification of the method of research and a sample of languages analyzed (Section 3); the issue of areal typology is briefly introduced in Section 4; an analysis of the data is provided in Section 5. The Conclusions section summarizes the results.

\section{Background}

\subsection{General}

\author{
And the raven, never flitting, still is sitting, still is sitting \\ On the pallid bust of Pallas just above my chamber door; \\ And his eyes have all the seeming of a demon's that is dreaming, \\ And the lamp-light o'er him streaming throws his shadow on the floor; \\ And my soul from out that shadow that lies floating on the floor \\ Shall be lifted-nevermore!
}

In 1845 Alan Edgar Poe loyal to his Poetry is the rhythmical creation of beauty in words wrote the world-famous poem Raven. Subsequently, he published in Graham's Magazine an essay The philosophy of composition where he inter alia accounted for choice of the refrain Nevermore.

The question now arose as to the character of the word. Having made up my mind to a refrain, the division of the poem into stanzas was, of course, a corollary: the refrain forming the close to each stanza. That such a close, to have force, must be sonorous and susceptible of protracted emphasis, admitted no doubt: and these considerations inevitably led me to the long $o$ as the most sonorous vowel, in connection with $r$ as the most producible consonant.

The sound of the refrain being thus determined, it became necessary to select a word embodying this sound, and at the same time in the fullest possible keeping with that melancholy which I had predetermined as the tone of the poem. In such a search it would have been absolutely impossible to overlook the word 'Nevermore.' In fact, it was the very first which presented itself.

Poe chose the word nevermore because of the strong 'o' sound, feeling that this particular vowel best expressed a feeling of sadness. Contemporary linguistics would probably cast doubts upon the idea that $[\mathrm{r}]$ is the most 'producible' consonant. However, Poe himself indirectly claimed the importance of sound symbolism in both language production and perception.

Sound symbolism or phonetic iconicity in various languages, ranging from Indo-European to Amero-Indian languages, was studied by many linguists, for example, Sapir [1929], Jespersen [1933], Ultan [1978], Nieunwehuis [1985], Diffltoth [1994] and Bauer [1996].

\footnotetext{
${ }^{2}$ Gregová, Körtvélyessy, Zimmermann [2010].
} 
Their efforts resulted in partial support to and partial denial of Universal \#1926 (originally \#1932) as formulated in Plank and Filimonova's Universals Archive:

There is an apparently universal iconic tendency in diminutives and augmentatives: diminutives tend to contain high front vowels, whereas augmentatives tend to contain high back vowels.

Anderson in his A Grammar of Iconism [1998: 106] points out that

\begin{abstract}
[s]ound symbolism usually is organized in terms of phonemic polarities or binary oppositions: front versus back, high versus low, rounded versus unrounded, acute versus grave, compact versus diffuse. These correlate with the discontinuities of human experience in terms of semantic contrasts or polarities, such as small versus large, proximate versus distant, weak versus strong, light versus dark, and so forth, in accordance with principle of phonemic relativism: the iconic potential of any given phoneme depends not on its inherent acoustic or kinesthetic features per se, but rather, on the extent to which these features lend themselves to contrasts within the phoneme system of the language...
\end{abstract}

This indicates link between phonetic iconicity and evaluative morphology understood by Štekauer [2010] as deviation from a standard, default value. This field, as many others in linguistics, can be viewed as a continuum with prototypical cases expressing the meaning of quantity under or above the default value (which may change from language to language, from speech community to speech community and, obviously, from situation to situation. This definition is more liberal than that proposed by Grandi [2002] who delimits the scope of evaluativeness along two axes: SMALL $\leftrightarrow$ BIG and GOOD $\leftrightarrow$ BAD. Stekauer's definition also encompasses, inter alia, attenuatives or deintensifiers, such as reddish (because reddish deviates from the default value of 'redness').

\title{
2.2. State of the art
}

Sound symbolism has been successfully exploited in poetry and fiction (level of parole). Its langue counterpart, the connection of sound symbolism and evaluative morphology at the level of language system also inspired a number of linguists to take up cross-linguistic research. In fact, there are several major cross-linguistic studies, in particular, those by Ultan [1978], Nieuwenhuis [1985] and Bauer [1996]. In spite of their unbalanced samples of languages they contributed to the examination of validity of the above-mentioned Universal. Two important conclusions have been drawn. First, it was pointed out that phonetic iconicity in evaluative morphology is not only bound to specific vowels. It was found out that fronted consonants are iconic symbols of diminutiveness, too. Second, it is assumed that, crosslinguistically, phonetic symbolism in evaluative morphology is primarily governed by the areal factor (Ultan [1978: 545]). This translates to the assumption that rather than of universal nature, phonetic symbolism in evaluative morphology is a phenomenon that occurs in certain geographically defined areas of the world. This is also confirmed by Bauer [1996: 201] who, on the basis of a sample of 50 languages, concludes that

[t]here does not appear to be any universal principle of sound symbolism operating in markers of the diminutive and augmentative such that palatal articulation correlates with diminutives and not with augmentatives.

Similar results are reported in Štekauer, Valera \& Körtvélyessy [2010] for a different sample of 55 languages.

Furthermore, Diffloth [1994] points out that iconic values of vowels in Bahnar expressives are High $=$ Big, Low $=$ Small, i.e., exactly the opposite to the postulated cross-linguistic situation.

Interesting results were arrived at within a research project at Šafárik University in Košice (Štekauer et al. [2009]). An analysis of four genera - the Slavic, the Germanic, the Romance and the Finno-Ugric - shows that in both diminutive and augmentative categories it is the 
front element that unambiguously prevails and, as a result, it is impossible to draw a line between the front marking of diminutives and the back marking of augmentatives. Furthermore, it was shown that the evaluative categories are most frequently expressed by complex markers combining iconic and non-iconic segments, which makes the process of iconicity evaluation most difficult. Neither the results obtained from a comparison of three groups of geographically and genetically different languages, including the Indo-European, the Austronesian and the Niger-Congo families (Gregová, Körtvélyessy, Zimmermann [2010]) confirm the postulate of universal iconic preference for front high vowels and front consonants in diminutives and back vowels and back consonants for augmentatives as claimed by Universal 1926 in Plank and Filimonova's Universals Archive. On the contrary, a detailed analysis of diminutive and augmentative affixes, supported by the frequency distribution histograms, indicates that front high vowels are typical of augmentatives rather than diminutives. Diminutive affixes are acoustically realized by central vowels. Similarly, the behaviour of consonants contradicts any universal expectations: front consonants slightly prevail in augmentatives and back consonants are typical of diminutives. In some languages, for example, Slovak, ${ }^{3}$ the process of palatalization changes the consonant before the diminutive affix, e.g. palic- $a$ 'stick' $>$ palič- $k$ - $a$ 'a little stick'. In any case, the abovementioned observations disregard any phonetic modifications due to affixation.

\section{Method and sample}

The current research data has been obtained by means of two different questionnaires.

Questionnaire 1: The questionnaire consists of a list of 35 core vocabulary items. The aim was to cover both the core vocabulary and four major word-classes: nouns, verbs, adjectives, and adverbs. The structure of the core vocabulary in terms of cognitive categories is as follows:

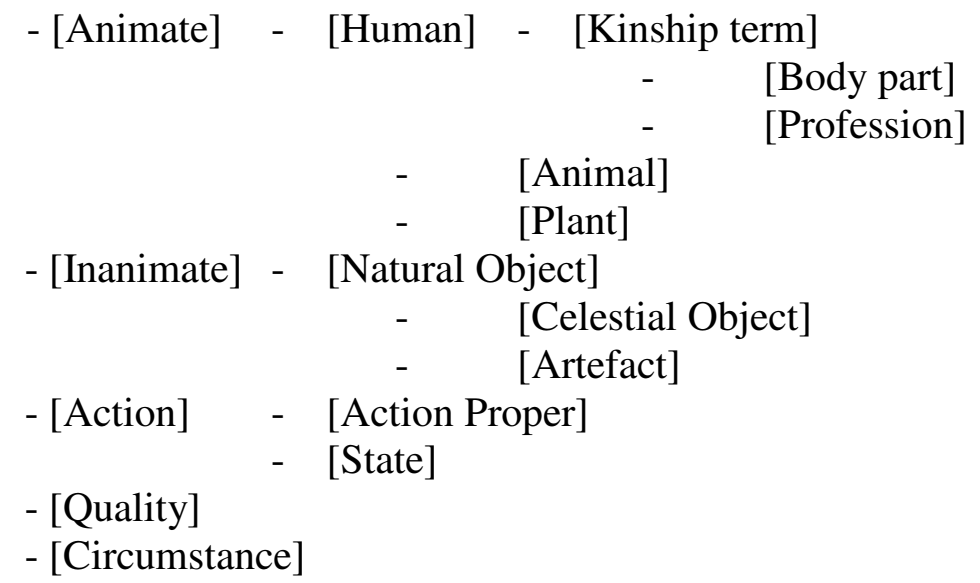

The data sheet with 35 lexical items was filled out by linguists. In case of several options of diminutive-formation for the individual lexical items only the most productive pattern was taken into account. Although the completed questionnaires gave us useful information, supplementary comments added by our informants proved to be a source of important details and instigated the development of another questionnaire - this time in the form of a data sheet.

\footnotetext{
${ }^{3}$ For more detailed analysis of the Slovak diminutives cf. Böhmerová (this volume).
} 
Questionnaire 2: The data sheet is divided into 4 sections:
A. Diminutives
B. Augmentatives
C. Semantic categories of Evaluative morphology
D. Word-classes

The basic question of the diminutive/augmentative section is: Does the language form DIMINUTIVE / AUGMENTATIVE morphologically? Various possibilities of morphological formation (prefixation, suffixation, infixation, transfixation, compounding, incorporation, reduplication, conversion) of diminutives and/or augmentatives are offered and the informants are asked for examples, including literal translation into English.

The second section focuses on semantic categories in evaluative morphology. The underlying question is: Can your language express the following semantic categories? The accompanying chart offers semantic categories of physical quantity, quantity of quality, quantity of action, gender, etc. The central question of the last section focuses on word-classes that can express diminutiveness/augmentativeness in a given language. Questionnaires were completed in two ways - either informants were approached or descriptive grammars of individual languages were used.

\section{Areal typology}

Areal typology is characterized by a relative paucity of literature, especially in comparison with other fields of typological research. By implication, the study of phonetic iconicity and evaluative morphology in terms of areal classification means, many times, work on untilled area. Given the main focus of this paper - the African languages, an important reference is Güldemann's (forthcoming) outline of a synchronic macro-areal profile of Africa. Güldemann suggests 5 language areas in Africa.

The collected questionnaires represent 16 languages. Table 1 and Figure 1 illustrate their genealogical classification and geographical areas.

\begin{tabular}{|l|l|l|l|}
\hline Language & Language family & Genus & Area \\
\hline Bafut & Niger-Congo & Bantoid & Cameroon \\
\hline Bemba & Niger-Congo & Bantoid & $\begin{array}{c}\text { Democratic } \\
\text { republic of Congo, } \\
\text { Southern Kivu } \\
\text { Province }\end{array}$ \\
\hline Luwanga & Niger-Congo & Bantoid & $\begin{array}{c}\text { Kenya, Lake } \\
\text { Victoria }\end{array}$ \\
\hline Kiluba & Niger-Congo & Bantoid & $\begin{array}{c}\text { Democratic } \\
\text { republic of Congo, } \\
\text { Katanga Province }\end{array}$ \\
\hline Xhosa & Niger-Congo & Bantoid & South Africa \\
\hline Zulu & Niger-Congo & Bantoid & South Africa \\
\hline Akan & Niger-Congo & Kwa & Ghana \\
\hline Yoruba & Niger-Congo & Defoid & Benin, Nigeria \\
\hline
\end{tabular}

\footnotetext{
4 The genealogical classification is based on WALS. If the language was not present there, the Ethnologue was used (e.g. in the case of language Mina).
} 


\begin{tabular}{|l|l|l|l|}
\hline Fur & Nilo-Saharan & Fur & Sudan \\
\hline Kanuri & Nilo-Saharan & Saharan & $\begin{array}{c}\text { Cha, Niger, } \\
\text { Nigeria, Sudan }\end{array}$ \\
\hline Koyra Chiini & Nilo-Saharan & Songhay & Mali \\
\hline Ma'di & $\begin{array}{c}\text { Nilo-Saharan, } \\
\text { Central Sudanic }\end{array}$ & Moru-Ma'di & Sudan, Uganda \\
\hline Siwi & Afro-Asiatic & Berber & Egypt \\
\hline Maale & Afro-Asiatic & North-Omotic & Ethiopia \\
\hline Mina & Afro-Asiatic & Biu-Mandara & Nothern camroon \\
\hline Nama Hottentot & Khoisan & Central Khoisan & Namibia \\
\hline
\end{tabular}

Table 1: The genealogical classification and areas of presence of 16 African languages
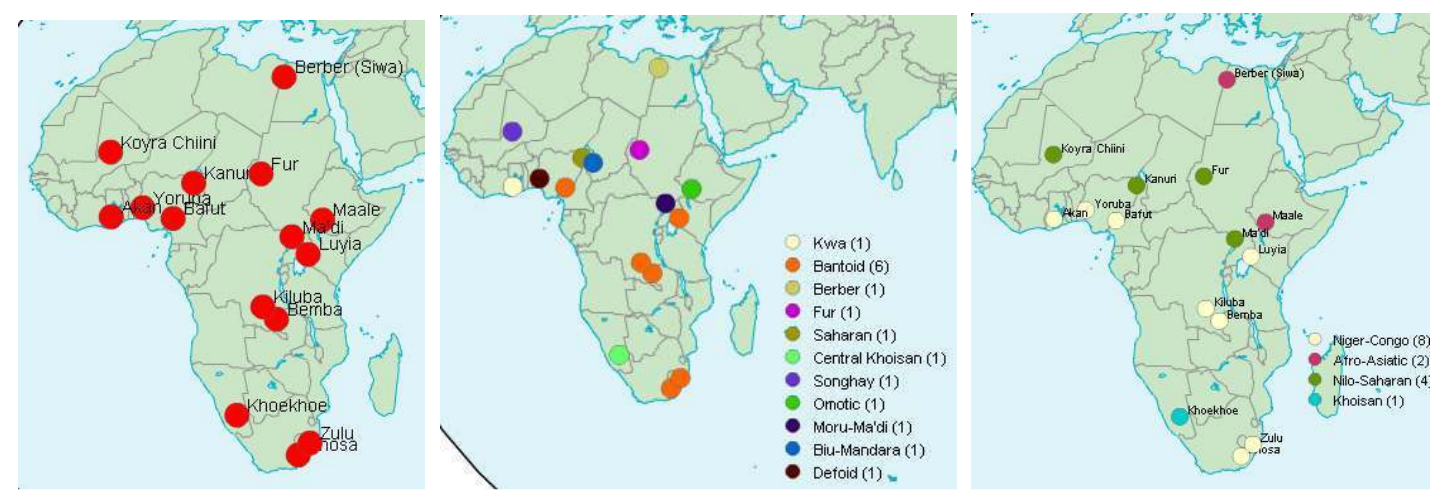

Figure 1: The genealogical classification and areas of presence of 16 African languages

Güldemann proposes 5 macro-areas of Africa:

(I) Sahara spread zone (Berber, Arabic)

(II) Chad-Ethiopia

(III) Macro-Sudan belt

(IV) Bantu spread zone

(V) Kalahari Basin

Each macro-area has its language representation in Table 1. Two languages were excluded from further analysis - Ma'di and Luwanga. They are spoken on a territory that belongs to a large area of southern Sudan, Uganda, Kenia, northern Tanzania. Güldemann characterizes it as an expansion area of Nilotic 'framed' by 4 fragmentation zones, typical of serious lack of data. For similar reasons the Kanuri language was dropped, too.

Table 2 and Figure 2 illustrate the fusion of Güldemann's linguistic areas and WALS information on sample languages. 


\begin{tabular}{|l|l|l|l|}
\hline Language area & $\begin{array}{l}\text { Language } \\
\text { Siwa }\end{array}$ & $\begin{array}{l}\text { Family } \\
\text { Afro-Asiatic }\end{array}$ & $\begin{array}{l}\text { Genus } \\
\text { Berber }\end{array}$ \\
\hline Sahara spread Zone & Koyra Chiini & Nilo-Saharan & Songhay \\
\hline & Fur & Nilo-Saharan & Fur \\
\hline Chad-Ethiopia & Maale & Afro-Asiatic & North-Omotic \\
\hline & Akan & Niger-Congo & Kwa \\
\hline Macro-Sudan belt & Yoruba & Niger-Congo & Defoid \\
\hline & Bafut & Niger-Congo & Bantoid \\
\hline & Bemba & Niger-Congo & Bantoid \\
\hline Bantu spread zone & Kiluba & Niger-Congo & Bantoid \\
\hline & Khoekhoe & Khoisan & Central Khoisan \\
\hline Kalahari Basin & Zulu & Niger-Congo & Bantoid \\
\hline & Xhosa & Niger-Congo & Bantoid \\
\hline
\end{tabular}

Table 2: Fusion of Güldemann linguistic areas and WALS

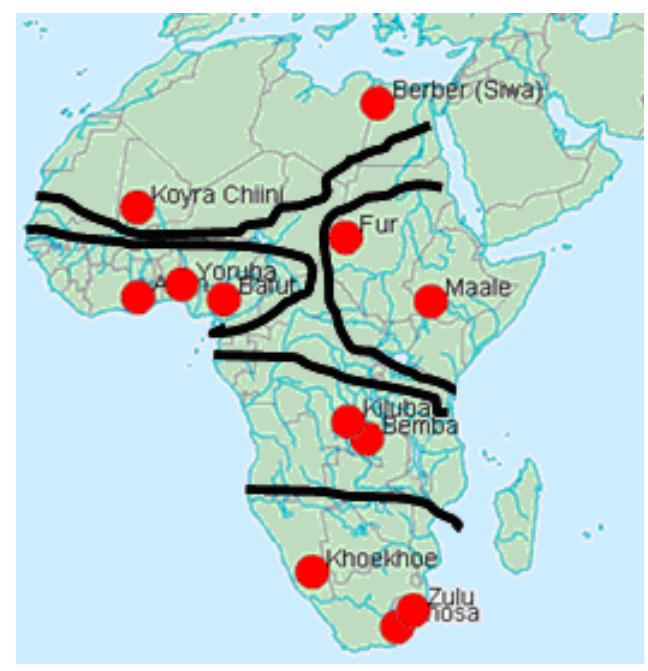

Figure 2: Fusion of Güldemann linguistic areas and WALS

\section{Analysis of the linguistic areas}

The analysis was based on three basic questions:

1. Is there Evaluative Morphology in the African language analyzed?

2. If yes, do the morphological markers comply with the iconicity hypothesis?

3. What are the differences between African and European languages in terms of phonetic iconicity?

\subsection{Is there Evaluative Morphology in the African languages analyzed?}

The following table overviews the presence of evaluative morphology in the languages under investigation. 


\begin{tabular}{|c|c|c|c|c|c|}
\hline \multirow[b]{3}{*}{ Area } & \multirow[b]{3}{*}{ Languages } & \multirow{3}{*}{$\begin{array}{l}\text { Is there } \\
\text { EM? }\end{array}$} & \multicolumn{3}{|c|}{ Iconic - Non-iconic } \\
\hline & & & \multicolumn{2}{|c|}{ Universal } & \multirow{2}{*}{$\begin{array}{c}\text { Ultan+Nieuwenhuis } \\
\text { DIM } \\
\end{array}$} \\
\hline & & & DIM & AUG & \\
\hline & Siwa & $m$ & $m$ & $m$ & $m$ \\
\hline \multirow[t]{2}{*}{$\begin{array}{l}\text { Sahara spread } \\
\text { Zone }\end{array}$} & $\begin{array}{l}\text { Koyra } \\
\text { Chiini }\end{array}$ & $\checkmark$ & $\checkmark$ & $x$ & $x$ \\
\hline & Fur & $m$ & $m$ & $m$ & m \\
\hline \multirow[t]{2}{*}{ Chad - Ethiopia } & Maale & $\checkmark$ & $x$ & $x$ & $x$ \\
\hline & Akan & $\checkmark$ & $x$ & $x$ & $x$ \\
\hline \multirow[t]{3}{*}{$\begin{array}{l}\text { Macro-Sudan } \\
\text { belt }\end{array}$} & Yoruba & $m$ & m & $m$ & m \\
\hline & Bafut & $\checkmark$ & $x$ & $x$ & $x$ \\
\hline & Bemba & $\checkmark$ & $x$ & $x$ & $x$ \\
\hline \multirow[t]{2}{*}{$\begin{array}{l}\text { Bantu spread } \\
\text { Zone }\end{array}$} & Kiluba & $\checkmark$ & $x$ & $x$ & $x$ \\
\hline & Kohoekbe & $\checkmark$ & $x$ & $x$ & $x$ \\
\hline \multirow[t]{2}{*}{ Kalahari Basin } & Xhosa & $\checkmark$ & $x$ & $x$ & $x$ \\
\hline & Zulu & $\checkmark$ & $x$ & $x$ & $x$ \\
\hline
\end{tabular}

Table 3: Presence of EM $\approx$ - no EM $\checkmark$ - yes $x$ - no

Evaluative Morphology is present in 9 of 12 African languages. The Kalahari Basin and Bantu Spread Zone completely match Güldemann's areal classification. One of three languages of the Macro-Sudan Belt - the Yoruba language (an isolating language) - lacks evaluative morphology. The Sahara spread Zone is represented by 2 geographically distant languages in my sample, and unfortunately without sufficient information on the Siwa language - no informant was available and the grammars do not offer this kind of information. On the other hand, the previously excluded languages - Kanuri, Maadi, Luwanga. Maadi are spoken on this territory; Luwanga makes use of evaluative morphology, Kanuri does not.

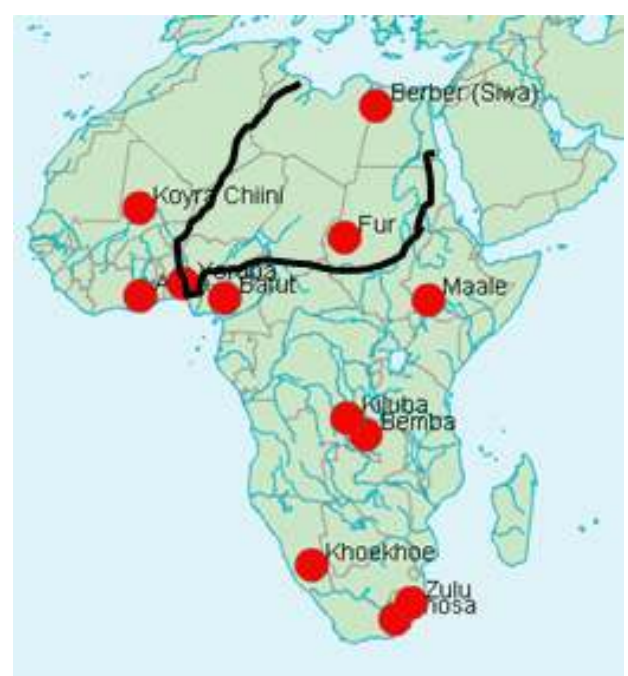

Figure 3: Linguistic areas of Africa and EM 


\subsection{Do the morphological markers comply with the iconicity hypothesis?}

In addition to the question of presence/absence of evaluative morphology in the languages under research, the nature of evaluative markers was studied. The attention was paid to their vocalic and consonantal iconicity.

The occurrence of purely front high vowels in the diminutive affixes in the languages of Africa is $0 \%$. Single-segment palatal (or alveo-palatal) consonants do not occur either. The occurrence of the combination front high vowel + alveopalatal/palatal consonant ${ }^{5}$ is also $0 \%$. An overview of the structure of evaluative markers in the sample languages is given Table 4 and Table 5.

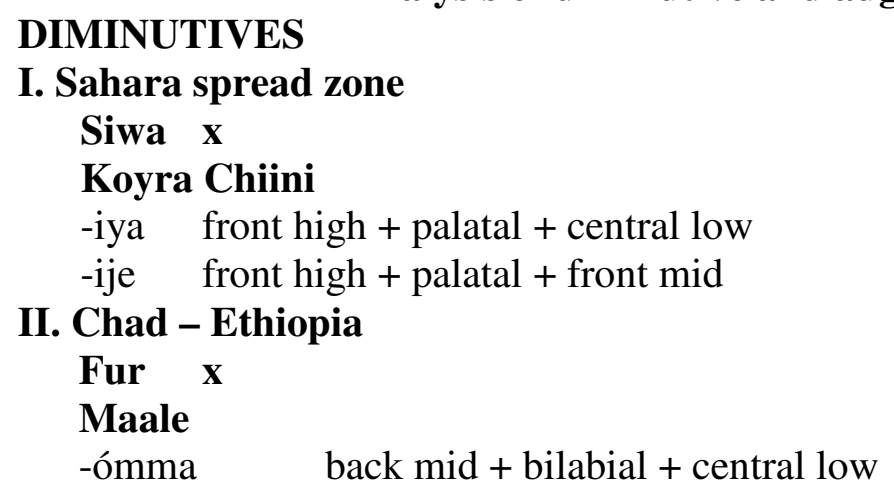

\section{Analysis of diminutive and augmentative affixes}

III. Macro-Sudan belt
Akan
ba- $\quad$ bilabial + central low
Yoruba $\quad x$
Bafut
mu- bilabial + back high
fi- labio-dental + front high
-to alveolar + central
IV. Bantu spread Zone
Bemba
kaa - $\quad$ velar + central low
aka- central low + velar + central low
atu - central low + alveolar + back high

Kiluba

ká- $\quad$ velar + central low
V. Kalahari Basin
Khoekbe
-ró alveolar + back mid
Xhosa
-ncinci dental alveolar + front high + dental alveolar + front high
-ana
central low + alveolar + central low

\footnotetext{
${ }^{5}$ All vowels of I-type were characterized as front high, E-type vowels were indicated as front mid, vowels of Atype are central low, vowels O-type are back mid, and all vowels of U-type were interpreted as back high. Consonants were divided into three categories based on the place of articulation: FRONT: bilabial, labio-dental, dental; MID: alveolar, palato-alveolar, palatal; BACK: velar, laryngeal. ${ }^{5}$
} 


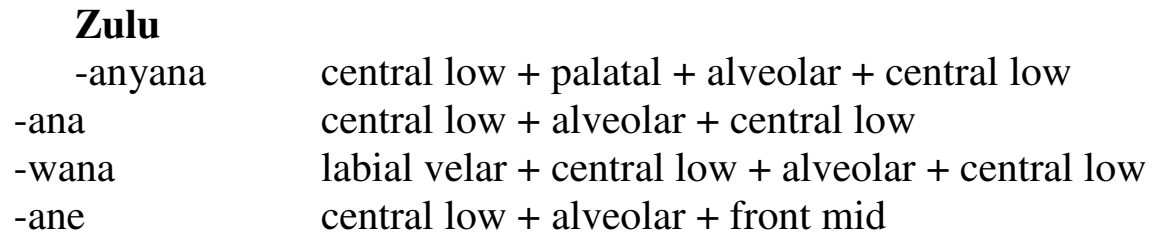

\section{Table 4: Analysis of diminutive affixes}

If a tendency to phonetic iconicity means only the 'appearance of a high front vowel and/or palatal/alveolar consonant', Koyra Chiini, Bafut, Bemba, Khoekbe, Xhosa, Zulu show this tendency. However, if only vowel sounds are taken into consideration (as proposed by the Universal), no more than three languages - Bafut, Xhosa and Koyra Chiini - can be included. Bafut has two diminutive prefixes and one suffix:

$$
\begin{aligned}
& \text { sing 'bird' < mu-sing 'birdie' } \\
& \text { ngo'o 'stone'< <i-ngo'o 'DIM+stone' } \\
& \text { tonge 'dig'< <ong-to 'dig + DIM' }
\end{aligned}
$$

Each of them consists of at least one iconic element - [m], [t], [i]. However, only [i] sound of the $f i$ - prefix corresponds with the Universal.

The case of Xhosa is even more confusing. Both diminutive suffixes contain iconic elements. On the other hand, the fully iconic -ncinci only appears in one word of the questionnaire:

$$
\text { ubawo'father' < ubawoncinci 'daddy }
$$

The vowel sounds of the second suffix -ana are non-iconic, only [n] is referred to as alveolar, thus iconic.

$$
\text { isando 'hammer' < isandwana 'hammer + DIM' }
$$

Neither Koyra Chiini can be unambiguously characterized as an iconic language. Heath [1999: 78] states that

The old Diminutive suffix -iya is preserved only vestigially in a few forms like bundiye 'brochette' < bundu stick, wood' and huriya 'knife'...plus a few flora-fauna terms like takiriya 'firefinch'.

On the other hand, he also mentions compounding to be a diminutive-forming process. Determinatum of the compound is -ije, whereas $X$-ije literally means 'child of $X$ ' in the sense 'a smaller entity associated with $X$ '. If $X$ denotes a physical object, $X$-ije denotes a smaller object physically associated with it or a small X. If X denotes a collectivity, mass, location, or abstraction, $X$-ije denotes an individual (Heath [1999: 78]). Considering the meaning of the compound, the meaning and the position of -ije never changes and preferably it can be referred to as a semiaffix and the process of coining diminutives in Koyra Chiini suffixation:

$$
\begin{aligned}
& \text { fufu-tondi-ije 'small grindstone' < fufu-tondi 'grinding stones' } \\
& \text { ferey-ije 'piece of brick' < ferrey 'brick' } \\
& \text { koyra-ije 'citizen, townsperson' < koyra 'town' }
\end{aligned}
$$

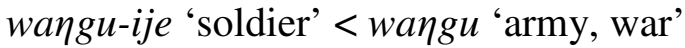


Nevertheless, if -ije is accounted for as a (semi)affix, it is the only iconic suffix in the sample of African languages.
AUGMENTATIVES
I. Sahara spread zone
Siwa $x$
Koyra Chiini x
II. Chad - Ethiopia
Fur $x$
Maale
-ats central low + post alveolar

III. Macro-Sudan belt

$\begin{array}{ll}\text { Akan } & \mathbf{x} \\ \text { Yoruba } & \mathbf{x} \\ \text { Bafut } & \\ \text { ma- } & \text { bilabial + central low }\end{array}$

IV. Bantu spread Zone

Bemba

cii- $\quad$ post-alveolar + front high

ici- $\quad$ front high + post-alveolar + front high

ifi- $\quad$ front high + labio-dental

Kiluba

kí- post-alveolar + front high

V. Kalahari Basin

Khoekbe

-kára $\quad$ velar + central low + alveolar +central low

Xhosa

-kazi velar + central low + dental-alveolar + front high

Zulu

-kazi $\quad$ velar + central low + alveolar + front high

Table 5: Analysis of augmentative affixes

Augmentative markers are used in nine out of twelve languages. Neither of them incorporates a back vowel; to the contrary, front high vowels are present - e.g. in Bemba:

(6) maayo 'mother' < ciimaayo 'AUG + mother utulo'sleep' < icitulo 'AUG+sleep'

and Kiluba:

(7) kíkiluwe 'hand'< kíkiluwe 'AUG+hand' 


\subsection{What are the differences between African and European languages in terms of phonetic iconicity?}

The research data for the languages of Europe show two major trends. ${ }^{6}$ First, morphological realization of the category of diminutiveness is much more common than that of augmentativeness. The same conclusion applies to the languages of Africa, which confirms a universal implicational relation 'IF Augmentative markers THEN diminutive markers' (cf., for example, Śtekauer, Valera and Körtvélyessy [to appear). Second, there are considerable ]differences between individual language families. While Slavic languages show 'affluence' of evaluative morphology without substantial differences between individual languages, ranging over all main word-classes, there are considerable differences inside the other language families examined, for example, between German and English, between Estonian and Hungarian, etc. African languages seem to be more homogeneous in terms of the number of evaluative markers per language, this number ranging from one to four.

The postulate of phonetic iconicity has not been confirmed for either European languages or African languages. On both continents the major part of evaluative markers is based on a combination of iconic and non-iconic elements.

The tendency towards iconicity in African augmentatives has not been confirmed either the results show totally opposite tendencies - similar to those mentioned by Diffloth [1994] for Bahnar languages where, as he states, high=Big and low=small. Similarly, the analysis of augmentative affixes in Slavic languages has revealed the predominance of two combinations front high vowel + MID consonant and front high vowel + MID consonant $+B A C K$ consonant. Morphological augmentatives in Germanic and Finno-Ugric languages are rare and do not permit us to draw any relevant conclusions in relation to phonetic iconicity. In Romance languages, most of the consonants are MID ones and most of vowels are central.

\section{Conclusions}

The basic aim of the study presented was to analyze the tendencies towards sound symbolism in the linguistic areas of Africa and to compare the results with previous conclusions. Following the Universal, the iconicity of vowels was tested and following the previous research by Ultan [1978] and Nieuwenhuis [1985], the iconicity of consonants was examined, too. Both analyses confirmed the results of research carried out on a sample of Indo-European and Austronesian languages - Universal \#1932 seems to be just one of linguistic disbeliefs. The verb seem is used by purpose in the previous sentence. The longer (and the deeper) I have been studying the phonetic iconicity in various languages the more persuaded I am that the synchronic study should be completed with diachronic analysis and harmonized with the principles of Natural Morphology (e.g. the vowel harmony rule overpowers the iconicity principle).

The second goal of the analysis - to point out the importance of areal classification of languages within the framework of Evaluative Morphology - was proved. In this case, no seem is necessary - the presence/absence of evaluative morphology in the sample languages of Africa closely match the linguistic areas as proposed by Güldemann.

\footnotetext{
6 Stekauer et al. [2009], the research encompassed 25 languages: Russian, Ukrainian, Belorussian, Czech, Slovak, Polish, Bulgarian, Serbian, Croatian, Slovenian, Macedonian; English, German, Swedish, Danish, Afrikaans; French, Italian, Romanian, Portuguese, Spanish, Catalan; Finnish, Hungarian, Estonian.
} 
At the very end, I would like to remind the readers that the presented text is based on a fraction of about 2,000 languages spoken in Africa. By implication, the results should be viewed with caution.

\section{Bibliography}

ANDERSON Earl R., A Grammar of Iconism, Fairleigh Dickinson University Press, 1998.

BAUER Laurie, "No Phonetic Iconicity in Evaluative Morphology?", Studia Linguistica, Vol. 50, 1996: 189-206.

BöHMERova Ada, Suffixal Diminutives and Augmentatives in Slovak - A Systemic View with Some Cross-Linguistic Considerations, Lexis 6, 2010: (forthcoming).

Diffloth Gerald, “i: big, a: small.”, in Hinton L., Nichols J., \& Ohala J. J. (eds.), Sound Symbolism, Cambridge University Press, 1994: 107-114.

GRANDI Nicola, Morfologie in contatto. Le costruzioni valutative nelle lingue del Mediterraneo, Milano, 2002.

Gregová Renáta, KörTVÉLYeSSY Lívia \& ZiMmermanN Július, "Phonetic Iconicity in the Evaluative Morphology of a sample of Indo-European, Niger-Congo and Austronesian Languages", Word Structure 2010, Vol. 3, No. 2: 156-180.

GÜLDEMANN Tom, forthcoming. "Sprachraum and Geography", in LAMELI Alfred, KEHREIN Roland \& RABANUS Stefan (eds.), The handbook of language mapping. Handbooks of Linguistics and Communication Science Series, Berlin, Mouton de Gruyter.

JESPERSEN Otto, Essentials of English Grammar, London, Allen and Unwin.

HASPELMATH Martin, "The European linguistic area: Standard Average European", in HASPELMATH Martin, KÖNIG Ekkehard, OESTERREICHER Wulf \& RAIBLE Wolfgang (eds.), Language typology and language universals. (Handbücher zur Sprach- und Kommunikationswissenschaft) Berlin, de Gruyter, 2001: 1492-1510.

HaSPELMATH Martin et al., The World Atlas of Languages Online, Munich, Max Planck Digital Library, 2008: Available online at http://wals.info/languoid\#name

HEATH Jeffrey, A Grammar of Koyra Chiini, Mouton, 1999.

NiEUWENHUIS Paul, Diminutives, PhD. Dissertation, University of Edinburgh, 1985.

PoE Alan Edgar, The Raven, first published in 1845.

PoE Alan Edgar, "The Philosophy of Composition", Graham's Magazine, Vol. XXVIII, no. 4, April 1846: 163-167.

Plank Frans and Filimonova Elena, The Universals Archive. Retrieved 10.10.2007 from http://ling.uni-konstanz.de/pages/proj/sprachbau.htm

SAPIR, Edward, “A Study in Phonetic Symbolism” Journal of Experimental psychology Vol. 12, 1996: 225-239

ŠTeKAUER Pavol, On some Issues of Diminutives from a cross-linguistic Perspective, unpublished paper, 2010.

Štekauer Pavol, Gregová Renáta, Kolaříková Zuzana, Körtvélyessy Lívia \& PANOCOVÁ Renáta, "On phonetic iconicity in evaluative morphology. Languages of Europe" in ŠTEKAUER, Pavol, TOMAŠČíKOVÁ Slávka \& WiTAŁISZ Wladisław (eds), Culture, Language and Literature Across Border Regions, Krosno, 2009.

ŠTeKauer Pavol, SAlvador Valera \& KörtvélyesSy Lívia, Word-Formation in the World's languages. A typological survey, Cambridge, Cambridge University Press (to be published).

UltaN Russel, "Size-sound symbolism”, in GREENBERG Joseph (ed.), Universals of Human Language, Vol. 2., Stanford, Stanford University Press, 1978: 525-568. 